\section{Combining bioengineering and plant conservation on a Mediterranean islet}

\author{
Tommaso La Mantia ${ }^{(1)}$, Giuseppe Messana ${ }^{(2)}$, Vincenzo Billeci ${ }^{(2)}$, Angelo \\ Dimarca $^{(2)}$, Maria Beatrice Del Signore ${ }^{(1)}$, Marilena Leanza ${ }^{(1)}$, Salvatore \\ Livreri Console $^{(2)}$, Giuseppe Maraventano ${ }^{(2)}$, Giuseppina Nicolini ${ }^{(2)}$, \\ Elena Prazzi ${ }^{(2)}$, Paola Quatrini ${ }^{(3)}$, Francesco Sanguedolce ${ }^{(2)}$, Gerry \\ Sorrentino ${ }^{(2)}$, Salvatore Pasta ${ }^{(1)}$
}

This paper reports the results of a bioengineering intervention within the Mediterranean Basin carried out at Lampedusa Island (Strait of Sicily) on the "Spiaggia dei Conigli", the only sand shore of all Sicilian territory where the sea turtle Caretta caretta lays its eggs every year. The erosion of the steep slope over the beach itself caused sensitive changes in the grain size of shore's sediment and reduced the area of the beach with fine sand suitable for $\mathrm{C}$. caretta oviposition. In order to reduce surface water flow and to stop erosion, several bioengineering options were adopted using only native plant species to preserve local botanical heritage and to prevent the local extinction of some species. One year after interventions, average plant establishment was about $90 \%$ and many species which were severely endangered before the action (i.e., Jacobaea maritima (L.) Pelser \& Meijden subsp. bicolor (Willd.) B. Nord. \& Greuter and Limoniastrum monopetalum (L.) Boiss.) are now at low risk. Micropropagation and inoculation with beneficial root microbial symbionts were successfully applied to selected species. Regular demographic and phytosociological monitoring on permanent plot areas enabled to quantify the effect of bioengineering techniques on plant percentage cover and plant survival. The combination of bioengineering, biotechnology, and agronomic practices applied on plants appears to be effective in increasing plant cover and preserving several locally endangered plant species. Results presented here suggest that erosion can be controlled without moving large quantities of soil and without planting tree species.

Keywords: Reforestation, Landscape, Protected area, Endangered plants, Lampedusa island

\section{Introduction}

The coastal areas of the Mediterranean and especially those of its islands are at great risk of environmental degradation (Anonymous 2002). To counter this risk, the EU has developed a number of projects, one of which concerns the protection of the habitats suitable for the loggerhead sea turtle, Caretta caretta. Within the EU-Project LIFE03 NAT/IT/000163 "Reduction of human impact on Caretta caretta and Tursiops truncatus and their conservation in Sicily", action $\mathrm{C} 1$ included bioengineering (Menegazzi \& Messana 2010), within an area of the nature reserve "Isola di Lampedusa" (Nicolini 2001). This action concerned the geomorphological and ecological restoration of the area upstream of the Spiaggia dei Conigli (beach of rabbits, hereafter indicated with the acronym SDC), one of the few Italian nesting sites of $C$. caretta (Prazzi et al. 2010). The work also included the reconstitution of the dirt road leading down to the beach, realized in the 1980s and maintained until 1996, which in the last few years has meteoric water. A road to the beach triggered major erosion of the steep slope over the beach itself and caused sensitive changes in the grain size of shore's sediment. This flow has swept soil and stones from the hillside between the road and beach downstream, altering the sand composition of the beach and making oviposition by sea turtles increasingly difficult (Bombace et al. 2001, Prazzi et al. 2010).

Moreover, the whole island was subject to intense degradation as a consequence of human colonisation, so that during the last 170 years local animal and plant species disappeared or underwent a severe depletion along with plant communities (La Mantia 2001, Pasta 2001, Pasta \& La Mantia 2003, La Mela Veca et al. 2003, La Mantia et al. 2005).

This work describes one of the first restoration projects concerning a Mediterranean beach based on the use of propagated autochthonous species, bioengineering techniques and microbial biotechnologies. become a preferential path for the flow of
(1) Dipartimento DEMETRA, Università di Palermo, v.le delle Scienze, Ed. 4, Ingr H, I90128 Palermo (Italy); (2) Legambiente Sicilia - Ente Gestore della Riserva Naturale “Isola di Lampedusa", v. Tripoli 3, I-90138 Palermo (Italy); (3) Dipartimento di Scienze e Tecnologie Molecolari e Biomolecolari, Università di Palermo, v.le delle Scienze, Ed. 16 - I-90128 Palermo (Italy)

@ Tommaso La Mantia (tommaso.lamantia@unipa.it)

Received: Nov 03, 2012 - Accepted: Nov 05, 2012

Citation: La Mantia T, Messana G, Billeci V, Dimarca A, Del Signore MB, Lenza M, Livreri Console S, Maraventano G, Nicolini G, Prazzi $E$, Quatrini $P$, Sanguedolce F, Sorrentino G, Pasta S, 2012. Combining bioengineering and plant conservation on a Mediterranean islet. iForest 5: 296-305 [online 2012-12-17] URL: http://www.sisef.it/iforest/contents? id=ifor0638-005

\section{Communicated by: Roberto Tognetti}

The aim of this study was to integrate the use of bioengineering techniques and biological conservation for the restoration of the SDC area and particularly: (i): to use propagation material exclusively from autochthonous plant species (herbs, grasses and shrubs) for revegetation to stop species loss and genetic pollution in Lampedusa Island; (ii): to apply agronomic techniques and seedlings inoculation with beneficial root microbial symbionts in order to enhance plant establishment; (iii): to evaluate the effect of different bioengineering techniques on the establishment rate of some key species.

Bioengineering techniques have been typically applied to mountain environments (Schiechtl 1991, Ferro 2006), while on coastal areas they have been seldom used, and mostly on dune ecosystems (Onori 2009, Tinelli et al. 2010). In recent times, an increasing attention has been paid on the idea of combining bioengineering purposes and ex situ conservation through the propagation of autochthonous species (Piotto \& Di Noi 2001, Piotto et al. 2010). In this work plants species were chosen on the basis of the results of previous investigations on the local vascular flora (Bartolo et al. 1990, La Mantia et al. 2009) and on the semi-natural and agricultural landscape of Lampedusa (Pasta 2001, Pasta \& La Mantia 2003, La Mantia et al. 2011, Pasta et al. 2012).

Beneficial soil fungi and nitrogen fixing bacteria play a crucial role in producing fundamental ecosystem services such as soil fertility, nutrient cycling and favouring plant community dynamics (Zahran 2001, Turrini 
Tab. 1 - Plant propagation method and establishment rate in the SDC area. The risk level of all endemic, rare and/or threatened vascular plants is reported according to IUCN classification (Conti et al. 1997). (EW): extinct in the wild; (CR): critically endangered; (EN): endangered; (VU): vulnerable; (LR): low risk; (DD): lack of data). A semi-quantitative evaluation of local rarity, mainly based on data from Pasta (2001) and La Mantia et al. (2009) is given within the fourth column: (rrr): extremely rare (n < 50 plants); (rr): very rare (50-200 plants); (r): rare (200-500 plants); (c): common; (lo): localized. For six extremely rare species the exact number of individuals is reported; $(+)$ : propagated by micropropagation; (pls): transplanted in situ. (\#): the original source (clump or seed) could not be determined; $(* *)$ : this species is extinct in the wild at Lampedusa; $(*)$ : native and artificially propagated individuals could not be distinguished; $(\wedge)$ : for species propagated in small numbers, the absolute value is shown rather than the percentage.

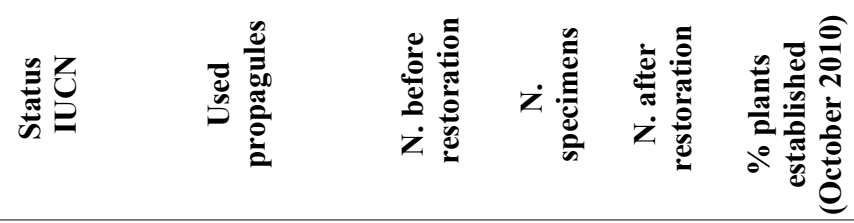

Endemics of Lampedusa island or Pelagie Archipelago

Lampedusa's Fleabane - Chiliadenus lopadusanus Brullo

Lampedusa's cliff pink - Dianthus rupicola Biv. subsp. lopadusanus Brullo \& Minissale

Lampedusa's sea-lavender - Limonium lopadusanum Brullo

Pelagian sand lily - Pancratium linosae Soldano \& F. Conti

Pelagian sea blite - Suaeda pelagica Bartolo, Brullo \& Pavone

$\begin{array}{cc}\text { VU } & \text { Clump (pls) } \\ - & \text { Seed } \\ \text { LR } & \text { Clump } \\ \text { EN } & \text { Seed } \\ \text { CR } & \text { Seed }\end{array}$

Endemic of Sicily, Sicily and Maltese Archipelago, S Italy and Sicily or central Mediterranean areas

Silver ragwort - Jacobaea maritima (L.) Pelser \& Meijden subsp. bicolor (Willd.) B. $\quad$ LR $\quad$ Seed

Nord. \& Greuter

(1)

Other rare, endangered, or nationally protected species

Cliff crossworts - Crucianella rupestris Guss.

Shrubby St John's Wort - Hypericum aegypticum L. subsp. webbii (Spach) N.K.B. Robson

Phoenician juniper - Juniperus turbinata Guss.

Limoniastrum - Limoniastrum monopetalum (L.) Boiss.

Matted boxthorn - Lycium intricatum Boiss.

UU

VU

VU

Wolfbane - Periploca angustifolia Labill.

Mediterranean Phagnalon - Phagnalon saxatile (L.) Cass. subsp. saxatile

Other rare or endangered species at the local level

Stinking bean trefoil - Anagyris foetida $\mathrm{L}$.

Strawberry tree - Arbutus unedo $\mathrm{L}^{+}$

Carob tree - Ceratonia siliqua L.

Fern-leaved clematis - Clematis cirrhosa $\mathrm{L}$.

Shrubby scorpion vetch - Coronilla valentina L. subsp. glauca (L.) Batt.

Mediterranean heath - Erica multiflora L. subsp. multiflora

Myrtle - Myrtus communis L.

Broad-leaved Phillyrea - Phillyrea latifolia L.

Common bramble - Rubus ulmifolius Schott

Other species

Wild asparagus - Asparagus acutifolius $\mathrm{L}$.

Branched asphodel - Asphodelus ramosus L.

Mediterranean saltbush - Atriplex halimus L.

Caper - Capparis spinosa L. subsp. rupestris (Sibth. \& Sm.) Nyman

Sea squill - Charybdys maritima (L.) Speta

Conehead thyme - Coridothymus capitatus (L.) Rchb. f.

Sea fennel - Crithmum maritimum L.

Tree spurge - Euphorbia dendroides L.

Pine spurge - Euphorbia pinea L.

Horned poppy - Glaucium flavum Crantz

Coolatai grass - Hyparrhenia hirta (L.) Stapf s.l.

Golden samphire - Limbarda crithmoides (L.) Dumort.

Shrubby Micromeria - Micromeria fruticulosa (Bertol.) Šilcič

Rock Phagnalon - Phagnalon rupestre (L.) DC. subsp. annoticum (Burnat) Pignatti

Lentisk - Pistacia lentiscus L.

White Hedge-nettle - Prasium majus L.

Fringe rue - Ruta chalepensis L.

Saltwort - Salsola oppositifolia Desf.

Shrubby seablite - Suaeda vera J.F. Gmelin

Shrubby Germander - Teucrium fruticans L.

Hairy Thymelaea - Thymelaea hirsuta (L.) Endl.

\begin{tabular}{|c|c|c|c|c|}
\hline Seed & $\mathrm{c}$ & 10 & 0 & 0.0 \\
\hline Seed & $\mathrm{c}$ & 23 & 1 & 25.0 \\
\hline Seed & $\mathrm{r}$ & 307 & 284 & 95.3 \\
\hline Seed & $\mathrm{rrr}$ & 32 & 28 & 87.5 \\
\hline Seed & - & 88 & 46 & 53.5 \\
\hline Rooted cuttings (pls) & $\mathrm{c}$ & 10 & 1 & 10.0 \\
\hline Clump & $\mathrm{c}$ & 5 & 0 & $0^{\wedge}$ \\
\hline Seed & - & 619 & 574 & 92.0 \\
\hline Clump & c & 9 & 3 & 37.5 \\
\hline Seed & - & 5 & 3 & $2^{\wedge} 0$ \\
\hline Seed & 5 & 179 & 106 & 67.5 \\
\hline Plants (by microprop.) & 1 & 24 & 22 & 91.7 \\
\hline Seed & $\mathrm{rrr}$ & 12 & 12 & 100.0 \\
\hline Plants & $\mathrm{r}$ & 10 & 0 & 0.0 \\
\hline Rooted cuttings & - & 10 & 0 & 0.0 \\
\hline Seed & 6 & 31 & 15 & 55.6 \\
\hline Seed & $\mathrm{rr}$ & 10 & 0 & 0.0 \\
\hline Seed & 4 & 281 & 177 & 63.4 \\
\hline Seed & $\mathrm{rr}$ & 31 & 13 & 86.7 \\
\hline Rooted cuttings & 3 & 2 & 2 & $2^{\wedge}$ \\
\hline Seed & - & 23 & 11 & 100.0 \\
\hline Clump (pls) & - & 105 & 77 & 79.4 \\
\hline Seed & - & 528 & 406 & 78.1 \\
\hline Seed & - & 36 & 8 & 88.9 \\
\hline Clump (pls) & - & 228 & 194 & 95.1 \\
\hline Seed & - & 115 & 30 & 40.0 \\
\hline Seed & - & 163 & 92 & 56.1 \\
\hline Seed & - & 358 & 180 & 57.7 \\
\hline Seed & - & 7 & - & n.d* \\
\hline Clump \# & - & 5 & - & 0.0 \\
\hline Seed \# & - & 23 & 18 & 72.0 \\
\hline Clump (pls) & - & 21 & 0 & 0.0 \\
\hline Plants & - & 161 & 65 & 59.1 \\
\hline Plants & - & 159 & 129 & 74.1 \\
\hline Clump & - & 10 & 7 & 70.0 \\
\hline Clump & - & 5 & 1 & $1^{\wedge}$ \\
\hline Clump (pls) & - & 5 & 1 & $1^{\wedge}$ \\
\hline Seed & - & 5 & 0 & 0.0 \\
\hline Seed & - & 441 & 376 & 87.0 \\
\hline Seed & - & 137 & 86 & 64.7 \\
\hline Rooted cuttings & - & 6 & 0 & $0.0^{\wedge}$ \\
\hline Seed & - & 38 & 34 & 91.9 \\
\hline Clump & - & 17 & 8 & 47.1 \\
\hline Seed & - & 9 & 10 & 90.9 \\
\hline Seed & - & 180 & 103 & 80.5 \\
\hline Rooted cuttings (pls) & - & 94 & 0 & 0.0 \\
\hline Clump (pls) & - & 12 & 9 & 75.0 \\
\hline
\end{tabular}


\& Giovannetti 2012). The diversity of bacteria and arbuscular mycorrhizal fungi (AMF) communities can decline due to habitat loss and anthropogenic disturbance and their reintroduction in the rhizosphere of greenhouse-propagated plants can help plant growth, productivity, health, and stress relief (Bothe et al. 2010).

The success of restoration actions was assessed in terms of vegetation cover and changes in the floristic composition of plots, by comparison with unaffected areas and by monitoring plant growth and survival within the restored sample plots.

\section{Materials and methods}

\section{Study area}

Lampedusa is the biggest island of Pelagie Archipelago (approx. $20 \mathrm{~km}^{2}$ ); it is located in the Strait of Sicily, some $115 \mathrm{~km}$ off the Tunisian coast and $195 \mathrm{~km}$ off Sicily (Fig. 1). The island is a triangular plateau with a quite uniform and slightly sloping surface. The southern coast is rugged, with numerous canyons, cliffs, and deep coves that often host sandy beaches the most famous of which is SDC. The average annual rainfall of Lampedusa is $321 \mathrm{~mm}$ with a pronounced concentration of precipitation in autumn and winter (La Mantia et al. 2011). Mean annual temperature is $19.3{ }^{\circ} \mathrm{C}$, with an average of $13.5^{\circ} \mathrm{C}$ in the coldest months (January and February) and $26.5^{\circ} \mathrm{C}$ in the warmest month (August). According to Rivas-Martínez (2008) classification, Lampedusa has a thermo-Mediterranean bio-climate, with a dry season that lasts about 6 months (from late February to late October).

The intervention area covered about 13000 $\mathrm{m}^{2}$ above the "Spiaggia dei Conigli" (Fig. 1 and Fig. 2). The area was subdivided on the basis of the restoration actions in seven erosion channels (A to $G$ ) that were subject to both planting and bioengineering treatments as described below, two areas $(\mathrm{H}, \mathrm{I})$ where only planting was realized (PO Planted Only), and two areas with jute nets only (J: Jute - Fig. 2). Other three areas were only subject to bioengineering interventions without planting (BO: Bioengineering Only); finally, one area not subject to erosion nor to any intervention was considered as control for plant cover evaluation (NSE: Not Subject to Erosion).

\section{Plant propagation, pre-planting and} planting techniques

Plant material for propagation was obtained from seeds, cuttings, or "clumps" (a clump included shoots, roots, and associated soil) and was collected in 2004 and 2005 on the slopes overlooking SDC and elsewhere at Lampedusa. Plant species and their mode of propagation are listed in Tab. 1. The standard abbreviation of the authors of the

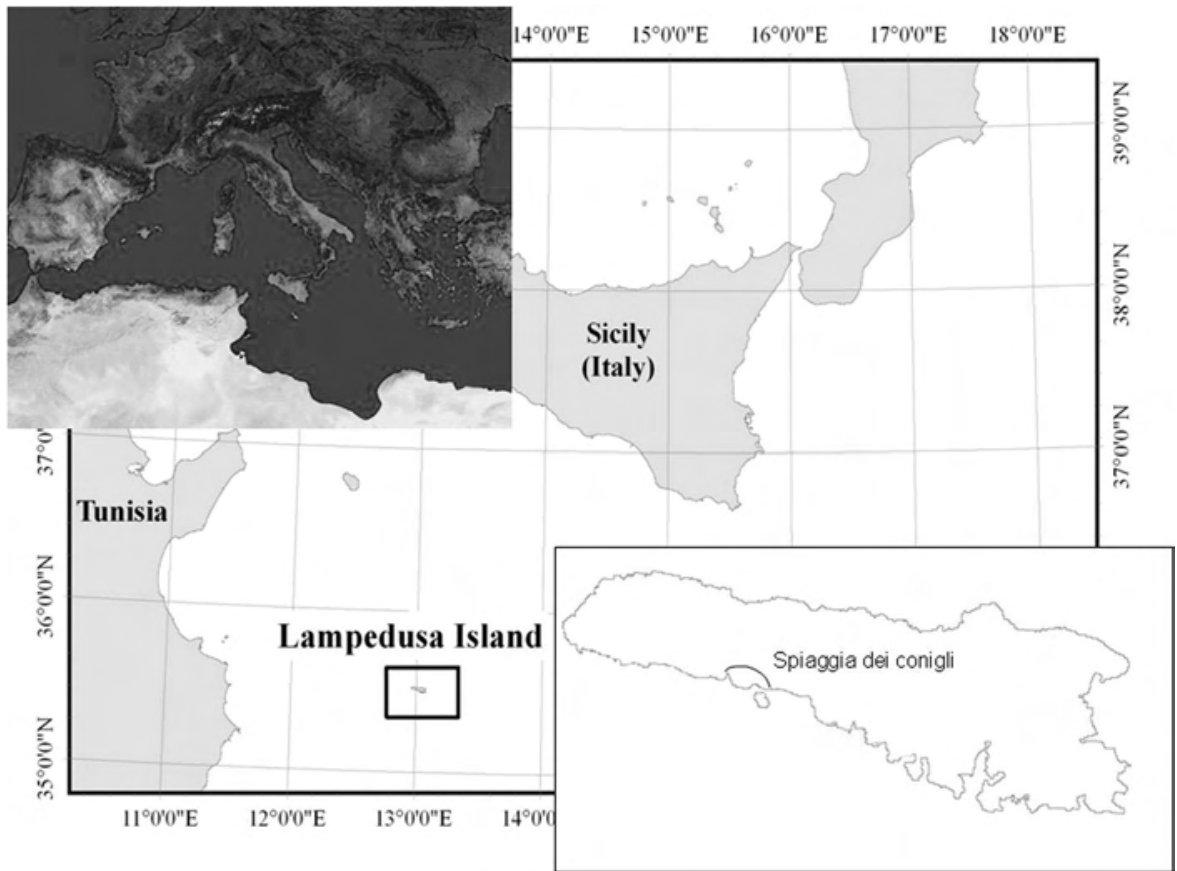

Fig. 1 - Location of Lampedusa Island.

scientific names concerning all the plants used for bioingeneering activities are reported on Tab. 1, while the authors of the other plants have been indicated when mentioned for the first time. A portion of plant material was propagated in a specialized private nursery in Sicily, then transferred and acclimatized at lampedusa local nursery of the Regional Agency of Forests, where other species (e.g., Juniperus turbinata, Capparis spinosa subsp. rupestris and Periploca an-

gustifolia) were also propagated. Perennial herbs and grasses (e.g., Asphodelus ramosus, Charybdis maritima and Hyparrhenia hirta) were usually propagated by use of the vegetative organs and were either directly transplanted from other sites of Lampedusa or radicated in the nursery before transplantation at SDC. Only Arbutus unedo was micropropagated in the laboratory by Legambiente (an environmentalist organization, encharged of the management of the nature reserve

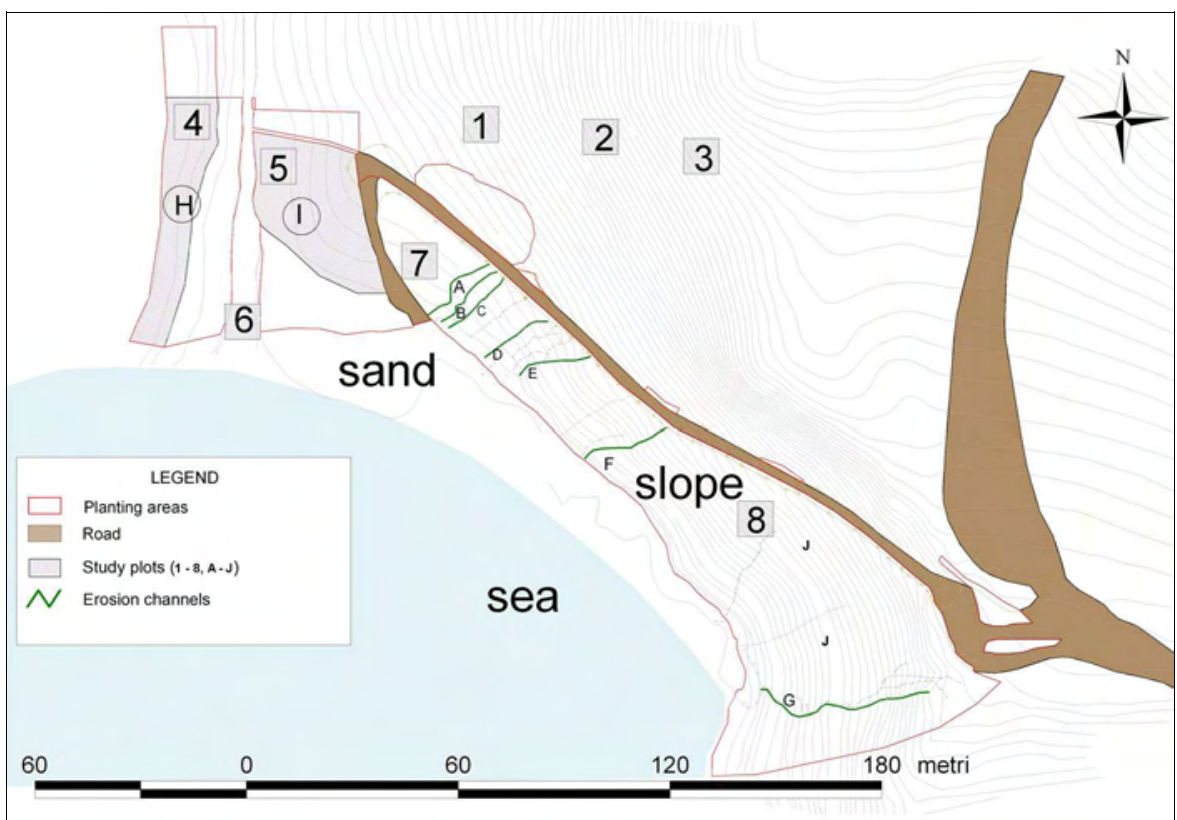

Fig. 2 - A map of "Spiaggia dei Conigli" where bioengineering and planting were carried out in order to reduce the erosion. See the text and Tab. 5 for explanation of study plots and planting areas. 

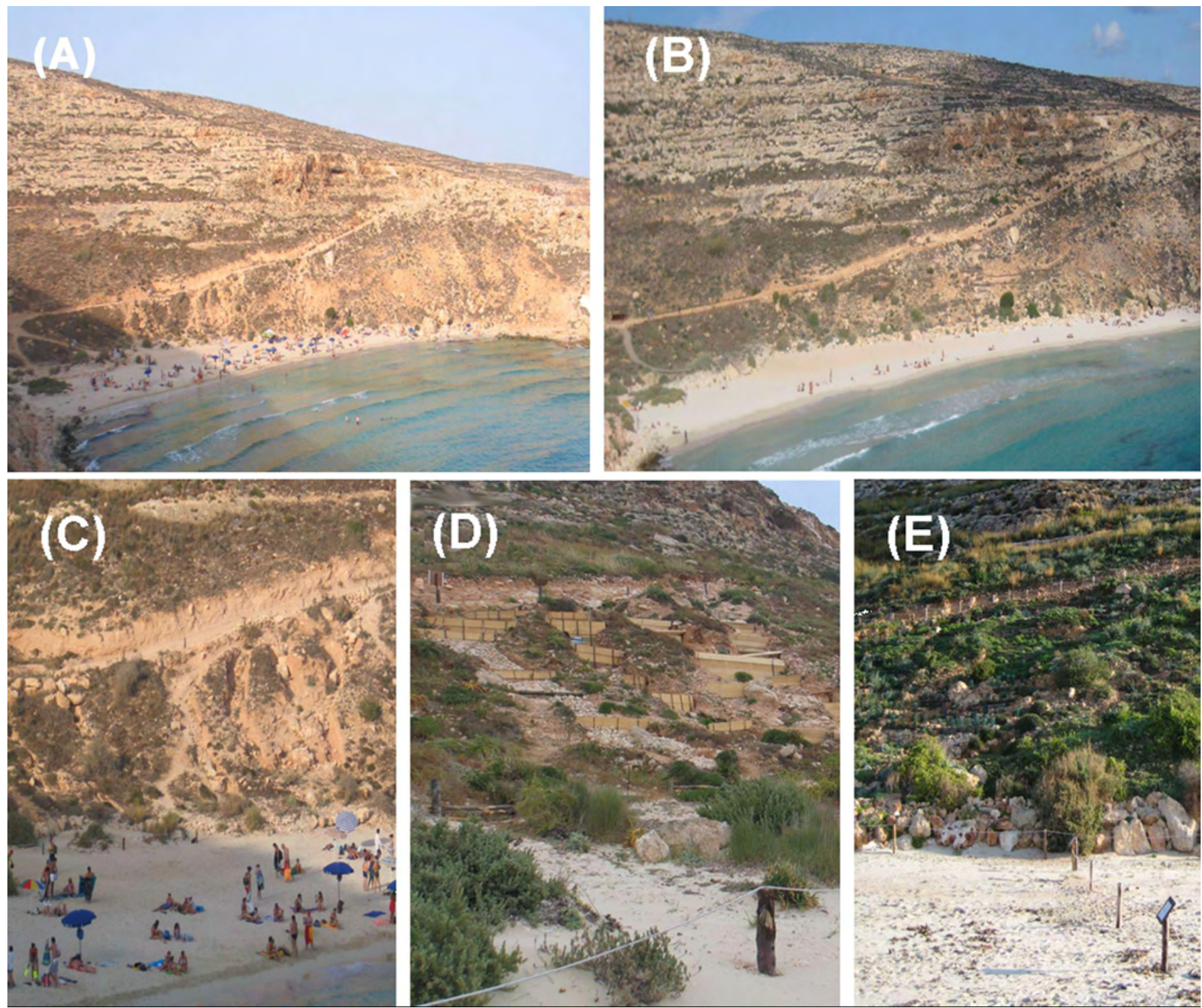

Fig. 3 - Pictures of the "Spiaggia dei Conigli" before and after the restoration. The beach, the hillside, and the road during summer 2005, before intervention: note the severe erosion on the hillside (A). In 2006, bioengineering was carried out to reduce soil erosion; woody fences and stones used to reduce erosion and increase plant establishment (B-D).The hillside in winter 2010, two years after the intervention (E).

"Isola di Lampedusa") at the laboratory site in nature reserve "Grotta di Carburangeli". Several woody species (Clematis cirrhosa, Lycium intricatum, Rubus ulmifolius, Ruta chalepensis, and Teucrium fruticans) were propagated by use of rooted cuttings, which were rooted directly in the field or in the nursery before transplantation in the field. During spring 2007, some 4883 specimens belonging to 43 different taxa (Tab. 1) were transplanted in the degraded area above SDC.

\section{Microbial inoculation}

A few plant species were also inoculated in the nursery at seedling phase with beneficial microbial symbionts to improve their fitness. Anagyris foetida was inoculated with a nitrogen-fixing Mesorhizobium strain isolated in
Sicily from $A$. foetida root nodules (Cardinale et al. 2008, 2010) and with a mix of a commercial inoculum of ectomycorrhizal fungi (MICOSAT $\mathrm{F}^{\circledR}$ VO12 WP, produced by CCS Aosta s.r.1., Italy) composed of a mix of crushed mycorrhizal roots and spores of endomycorrhizal fungi and mycelia of the genus Glomus (G. mosseae, G. intraradices, G. viscosum, G. coronatum and G. caledonium) and saprotrophic fungi (Tricoderma viride). Atriplex halimus, Ceratonia siliqua, Coronilla valentina subsp. glauca, Dianthus rupicola subsp. lopadusanus were treated with the above mentioned commercial inoculum together with spores and mycelium of ectomycorrhizal fungi, such as Tuber uncinatum, Hebeloma spp., Coenococcum spp., and saprophytic fungi, Tricoderma herthianum. Inoculation on Ceratonia siliqua was carried out on 1-year old plants. The effects of microbial inoculation were analysed once in the nursery as for growth parameters and once in the field as for survival rate, and compared to uninoculated plants.

\section{Agronomic practices and protection} against herbivores

During the first year after planting, all plants were irrigated (monthly during summer, when needed during winter). In order to defend plants from rabbits, an extract of garlic (Allium sativum L. - garlic cloves soaked in water for 2 days) was applied by spraying (several garlic based repellents for rabbits are used and patented in the United States). Larger plants were protected with cylinders of green, stiff plastic net (shelters). 
Fig. 4 - Some details of the different bioengineering techniques applied in the study area: woody fences (A),

woody fences filled with stones (B), felt mats (C), vegetative pockets made of bio-

mat (D), jute nets (F), jute nets after two years stopped erosion processes enhancing shrubs' growth (E). A particular of the shelters to avoid rabbit grazing $(\mathrm{G})$.
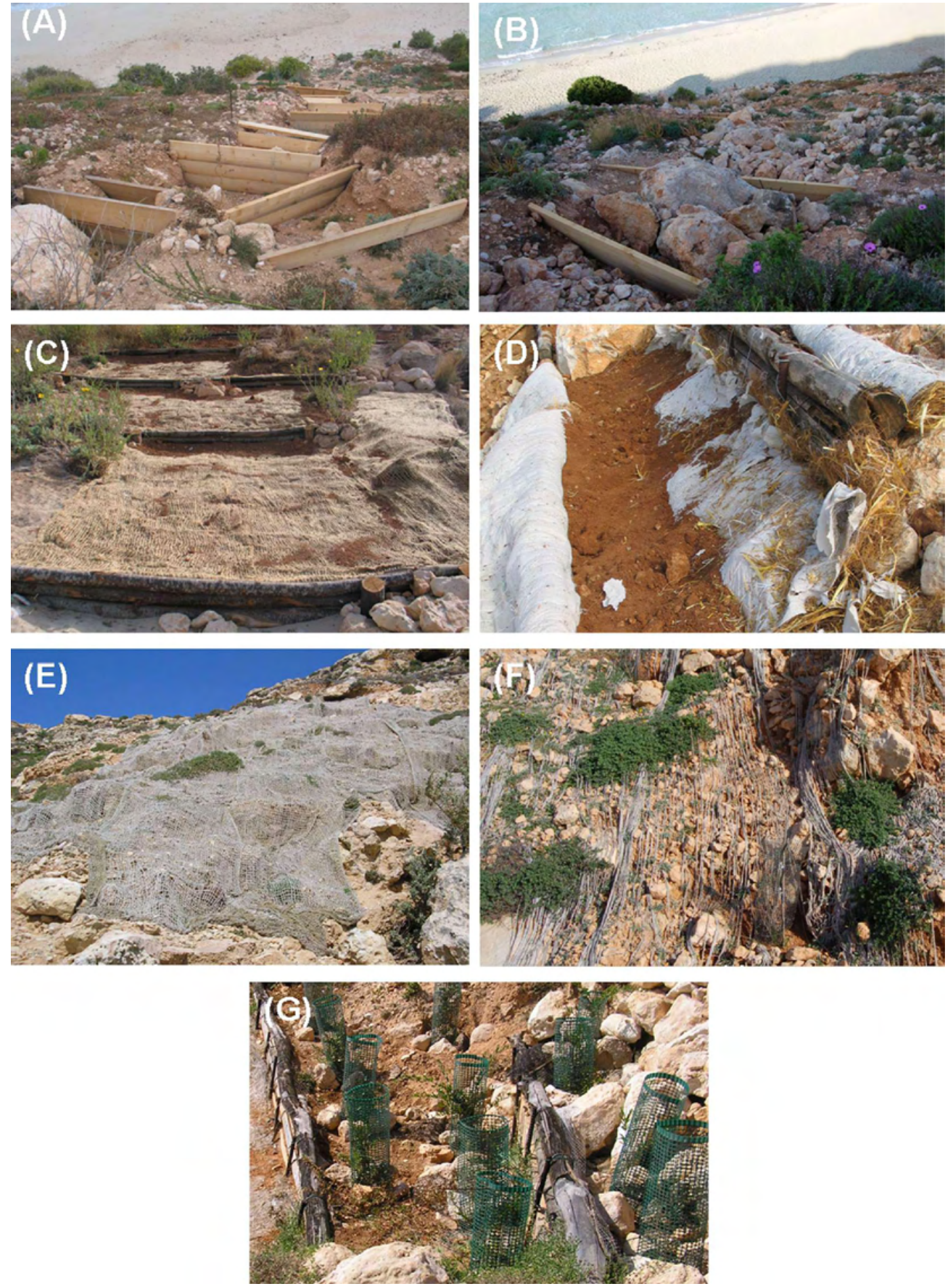

\section{Bioengineering techniques}

Bioengineering included the construction of 13 fences to reduce water flow and soil erosion (Fig. 3). Fences were made with chestnut boards and poles, and built up across eroded areas (A to G - Fig. 4). The fence height ranged from 0.3 to $1.5 \mathrm{~m}$, depending on the depth of the eroded channel. The eroded channels above the fences were filled with various combinations of sand, soil, stones, "felt mats", and "biomats". In order to fill some channels, the stones previously rolled down from the slope were reused. The felt mats consisted of wood residue in a polypropylene mesh ("Ecofelt W 200", "Biofeltro" of Harpo S.p.A., Trieste, Italy).

The biomats ("Stcmat", "Geostuoia biodegradabile", Harpo S.p.A.) consisted of coconut fiber. When an eroded channel was very deep, "vegetative pockets" were formed by placing a felt mat or biomat at the bottom of the channel and filling it with soil, sand, or stones. Additional details on these materials are provided by Menegazzi \& Messana (2010). Where the erosion had removed nearly all soil layer so that only stone outcrops remained, these were covered with jute nets ("Geojuta", "Georete antierosione biodegradabile", Harpo S.p.A.).

Three fences were placed across channels filled with soil (FeSo), six were placed across channels filled with sandy soil 
(FeSSo), and two were placed across channels filled with stones and soil (FeStSo). One fence was placed across a channel on the steep part of the slope, and the channel was filled with vegetative pocket containing stones [FeStVp(slope)]; another one was placed across a channel that was filled with stones, soil, and biomat (FeStSoB); another else was placed across a channel and filled with a vegetative pocket containing sand $[\mathrm{FeVp}$ (sand)]. In two cases, channels without fences were filled with vegetative pockets and biomats $(\mathrm{VpB})$ and with vegetative pockets, biomat, and stones (VpBSt). Fig. 4 illustrates some of the techniques and materials used in order to build up fences. Plants were then transplanted inside these areas.

To reduce disturbance and costs, the bioengineering was performed without heavy equipment. Most of the work was hand-made with shovels, wheel barrows, and other simple tools.

Plant survival and assemblage dynamics monitoring activities

The area was subdivided on the basis of the restoration actions (see study area) and a different combination of selected plant species were used according to their peculiar requirements. For example, Myrtle tree was used only in upper sectors, while Crithmum maritimum was preferred near the sand shore. On the other hand, the species with a wider ecological range and used in large amounts (Periploca angustifolia, Euphorbia dendroides, Pistacia lentiscus, Juniperus turbinata and Lycium intricatum) have been used in many sectors all over the intervention areas. Plant establishment was monitored by field surveys carried out on June 2007, March 2009 and October 2010, when all individuals were checked. The survey concerned the erosion channels subject to eight differen bioengineering interventions and planting (within areas $A$ to $\mathrm{G}$ ) and two areas $(\mathrm{H}$ and I) for an overall surface of about $2210 \mathrm{~m}^{2}$ (about $18 \%$ of the entire area involved in the intervention) where 332 specimens had been planted without any bioengineering (Fig 2).The change of both floristic composition and percentage cover in areas affected and

unaffected by interventions was surveyed through repeated phytosociological Relevées (Braun-Blanquet 1932) in October 2006, April 2007, April 2008, April 2009. These where carried out on an area not subject to erosion adjacent to the areas of intervention (plots 1-3 NSE), on planted areas H and I without bioengineering (plots 4-5), on areas subject to bioengineering that were not planted (plots 6-8) and in all the erosion channels (A-G) distinguishing the eight different bioengineering techniques applied (Fig. 2 and Fig. 4). Classification of vascular plants was based on Pignatti (1982), while their nomenclatural treatment mainly follows Conti et al. (2005).

\section{Results}

\section{Plant survival and establishment}

A total of 4883 specimens of 43 different taxa were transplanted to restore the area above SDC (Tab. 1). During the first survey, just one year after plantation (June 2007), $10.5 \%$ of the plants were dead (data not shown); the highest mortality was detected for Hyparrhenia hirta, Myrtus communis, Dianthus rupicola subsp. lopadusanus, and Chiliadenus lopadusanus (transplanted as clumps - Tab. 1). Transplantation was generally more successful when plants were first grown in pots in the nursery rather than directly transferred from adjacent field sites (Tab. 1). Our results confirm that seeding is more effective than transplanting in particular for Periploca angustifolia (Ennajeh et al. 2010). At the second (March 2009) and third survey (October 2010 - Tab. 1), the number of additional dead plants was nearly zero.

Either endemic (e.g., Dianthus rupicola subsp. lopadusanus, Pancratium linosae and Suaeda pelagica) or critically endangered species have been successfully propagated (Tab. 1). The most noteworthy success is represented by Jacobaea maritima subsp. Bicolor, locally extinct in the wild since ten years: some 50 plants coming from a branch collected from the last survivor now live in SDC. Thanks to the survival of planted material, it has been possible to increase the local number of individuals representing

Tab. 2 - Effect of microbial inoculation on plant height and field establishment. Plants were inoculated in the nursery as described in the "Materials and Methods" section and their height was measured after 9 months of growth (after 23 months for Ceratonia siliqua). Plant establishment in the field was measured after 1 year from transplantation.

\section{Plant species}

\section{Anagyris foetida}

Atriplex halimus

Coronilla valentina subsp. glauca

Ceratonia siliqua

Dianthus rupicola subsp.

lopadusanus

\section{Plant height (cm) Plant establishment (\%)} Inoculated Not inoculated Inoculated Not inoculated

$28.6 \pm 1.1 \quad 28.6 \pm 1.7 \quad 68 \quad 33$

$20.0 \pm 1.4$

$4.2 \pm 0.5$

$7.9 \pm 0.9$

82

58

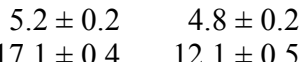

100

95

61

27

100

$12.1 \pm 0.5$ several other extremely rare species such as Anagyris foetida, Arbutus unedo, Ceratonia siliqua, Coronilla valentina subsp. glauca, Limoniastrum monopetalum, Myrtus communis, Phillyrea latifolia and Rubus ulmifolius. Moreover, ex situ propagation prevented the total extinction of Erica multiflora subsp. multiflora, intermediate sea-lavender Limonium intermedium (Guss.) Brullo and to increase the abundance of Rosemary Rosmarinus officinalis L., whose local population is currently represented by three plants only.

Once planted material survived the stress connected with the initial stages of transplanting, the plants appeared permanently established. Notwithstanding soil shallowness, slope steepness, southern aspect, the influence of salt spray and the very harsh local climate, the remarkably high survival rate was probably due to the prompt and regular cultural practices, especially irrigation. Irrigation is a practice rarely used due to lack of water, but crucial to the successful plantation in arid Mediterranean areas (Vallejo et al. 2006).

The effect of microbial inoculation with mycorrhizal fungi (and rhizobia on $A$. foetida) on plant establishment was high in Anagyris foetida and Coronilla valentina subsp. glauca that almost doubled their survival when inoculated, in respect to uninoculated controls (Tab. 2). Inoculation increased also the establishment of Dianthus rupicola subsp. lopadusanus and Atriplex halimus by $25 \%$. Effects of inoculation revealed that $A t$ riplex halimus, Coronilla valentina subsp. glauca and Dianthus rupicola subsp. lopadusanus were the more responsive to microbial inoculation, while Ceratonia siliqua and Anagyris foetida appear indifferent to microbial inoculation. Symbiotic interactions could have established with naturally occurring mycorrhizal fungi (and rhizobia in the case of $A$. foetida) in the soil, but no attempts (control) were made to confirm this hypothesis.

In the first days after planting, dozens of plants, including members of species known to be unattractive to rabbits, were bitten and their roots were in some cases undermined and damaged. Giving the name of SDC, it was not surprising that wild rabbits (Oryctolagus cuniculus L.) represented a serious threat to young plants. The garlic spray seemed to repel the rabbits only for 3 days; however, once plastic net protections were applied, the damaged plants rapidly recovered.

Effect of different bioengineering techniques on the establishment rate of some key species

The success of planting efforts was greatly affected by the applied bioengineering techniques and was strictly related to the ecology 
Tab. 3 - Establishment rate of some key species. (a): areas where no environmental engineering was carried out.

\begin{tabular}{|c|c|c|c|c|c|c|c|}
\hline Bioengineering techniques & Code & $\begin{array}{c}\text { Periploca } \\
\text { angustifolia }\end{array}$ & $\begin{array}{l}\text { Euphorbia } \\
\text { dendroides }\end{array}$ & $\begin{array}{c}\text { Pistacia } \\
\text { lentiscus }\end{array}$ & $\begin{array}{l}\text { Juniperus } \\
\text { turbinata }\end{array}$ & $\begin{array}{c}\text { Lycium } \\
\text { intricatum }\end{array}$ & $\begin{array}{c}\text { Dianthus } \\
\text { rupicola } \\
\text { subsp. } \\
\text { lopadusanus }\end{array}$ \\
\hline Planting only ${ }^{(a)}$ & PO & 88.85 & 90 & 88.55 & 96.65 & 48 & 84.6 \\
\hline Fences plus stones and soil & FeStSo & 95.9 & 75 & 83.9 & - & 0 & 100 \\
\hline Fences plus stones, soil, and biomat & FeStSoB & 80 & 0 & 87.5 & 50 & - & 66.7 \\
\hline Fences plus soil & FeSo & 100 & - & 90.9 & 90 & - & 50 \\
\hline Fences plus sandy soil & FeSSo & 100 & - & - & - & 30.8 & - \\
\hline Fences and vegetative pockets on the sand & $\mathrm{FeVp}$ (sand) & 0 & - & - & - & 50 & - \\
\hline Fences, stones, and vegetative pockets (slope) & FeStVp(slope) & 87.5 & 58.3 & 100 & 100 & 33.3 & - \\
\hline Vegetative pockets and biomat & $\mathrm{VpB}$ & 36.4 & 35.7 & - & 100 & 0 & - \\
\hline Vegetative pockets, biomat, and stones & VpBSt & - & 40 & 100 & - & - & 100 \\
\hline
\end{tabular}

of species (Fig. 4B to E - Tab. 3). As shown in Tab. 3, survival was high for all species planted in areas not subject to biongineering techniques (PO) with the exception of $L y$ cium intricatum whose survival was lower than $50 \%$. Lycium intricatum is a species of dryland areas and poor soils (Wickens 1998), and is utilized in restoration of arid soils (Padilla et al. 2009). Similarly the survival of Periploca angustifolia, a species of dryland areas (Le Houérou 2004), is decreased on sites where bioengineering was applied with addition of vegetative pockets and biomat. Euphorbia dendroides was not positively affected by interventions, probably because adapted to rocky and steep slopes rather than stony soils (Eichberger 2001, Brullo et al. 2010)

Dianthus rupicola subsp. lopadusanus is favoured by stones, on the contrary Juniperus turbinata reduces its survival only on stony substrates. Finally, Pistacia lentiscus shows an high survival in all conditions and confirms the excellent role played on intervention of restoration in Mediterranean countries (Maestre et al. 2006, De Dato et al. 2009)

\section{Assemblage dynamics}

As for the control areas bordering the areas of intervention, not affected by erosion and neither planted nor engineered (NSE - Fig. 2 ), percentage vegetation cover was relatively constant (plots $1-2$ ) or increased $(>10 \%$, plot 3 - Tab. 4). The annual variation in vegetation cover in plots 1-3 was small but noticeable, as expected for ephemeral prairies under xeric local climate. Plots 4-5 (planted only, PO) registered the highest cover increase underlining the role played by planting. As expected, in areas subject to bioengineering only (BO, plots 6-8) the cover is constant or slightly decreasing in the last survey. Bioengineering without planting (plots 6-8) or lack of any intervention (plots 1-3) as in control areas, makes the process of vegetation recovery likely slow.

In areas subject to bioengineering using fences, soil, biomat and planting, the reco- very of native vegetation was substantially accelerated (Tab. 5), as demonstrated by the increase (average $45 \%$ ) of the vegetation cover. A low increase in the cover of vegetation in areas with jute nets is likely due to the particularly harsh conditions caused by outcropping rock.

In the other bioengineering interventions [FeStSoB,FeVp(sand), FeStVp(slope) and VpBSt], the diffuse unevenness of the area did not allow to establish any replications. However the observed vegetation cover changes between 2006 and 2009 were positive (from 3 to 55 for FeStSoB, from 15 to 70 for $\mathrm{FeStVp}$ (slope) and from 3 to 5 for VpBSt). The only exception was detected in the $\mathrm{FeVp}$ (sand) treatment where a cover of 15 for the whole period of observations was recorded (data not shown).

The diachronic analysis of phytosociological relevés (data not shown), carried out during the 2 years following planting of the degraded area above SDC, clearly indicated that coverage increase was more sensitive among perennial species (chamaephytes and hemicryptophytes), performing better than annual species: this was the case of Pine spurge Euphorbia pinea, Mallow bindweed Convolvulus althaeoides L., Grey bird's foot trefoil Lotus cytisoides L., and Seedhead Reichardia picroides (L.) Roth. Substantial growth was also evident for some therophytes typical of ephemeral prairies such as Mediterranean needle grass Stipa capensis Thunb., Purple false brome Trachynia dista-

Tab. 5 - Changes in vegetation cover in the erosion channel (\%) before intervention (2006) and after intervention (2007 and 2009) according to phytosociological surveys. The abbreviations of the Bioengineering techniques are reported in Tab. 3. Only bioengineering interventions repeated at least in two different sites are reported.

\begin{tabular}{|c|c|c|c|c|c|c|c|c|c|c|c|c|c|c|c|}
\hline \multirow{3}{*}{ Yrs } & \multicolumn{15}{|c|}{ Bioengineering interventions } \\
\hline & \multicolumn{3}{|c|}{ FeSo } & \multicolumn{6}{|c|}{ FeSSo } & \multicolumn{2}{|c|}{ FeStSo } & \multicolumn{2}{|c|}{ VpB } & \multicolumn{2}{|c|}{ Jute nets } \\
\hline & $\mathbf{A}$ & B & $\mathbf{C}$ & $\mathbf{A}$ & B & $\mathbf{C}$ & $\mathbf{D}$ & $\mathbf{E}$ & $\mathbf{F}$ & D & $\mathbf{E}$ & D & $\mathbf{E}$ & J1 & $\mathbf{J} 2$ \\
\hline 006 & 15 & 55 & 45 & 15 & 55 & 45 & 10 & 5 & 3 & 10 & 5 & 10 & 5 & 5 & 7 \\
\hline 2007 & 65 & 45 & 35 & 15 & 15 & 15 & 65 & 20 & 15 & 55 & 30 & 20 & 10 & 10 & 12 \\
\hline 2009 & 90 & 70 & 84 & 70 & 50 & 55 & 95 & 50 & 20 & 100 & 95 & 75 & 30 & 25 & 25 \\
\hline
\end{tabular}

Tab. 4 - Changes in vegetation cover in sample plots and test areas before intervention (2006) and after intervention (2007 and 2009) according to phytosociological surveys. (NSE): not subject to erosion and not planted; (PO): planted only, i.e., without bioengineering; (BO): bioengineering only, i.e., without planting.

\begin{tabular}{lclll}
\hline \multirow{2}{*}{$\begin{array}{l}\text { Treat- } \\
\text { ments }\end{array}$} & Plots & \multicolumn{3}{c}{ Total cover (\%) } \\
\cline { 3 - 5 } & & $\mathbf{2 0 0 6}$ & $\mathbf{2 0 0 7}$ & $\mathbf{2 0 0 9}$ \\
\hline NSE & 1 & 45 & 40 & 40 \\
& 2 & 45 & 50 & 50 \\
& 3 & 65 & 90 & 100 \\
& Average & 51.7 & 60.0 & 63.3 \\
PO & 4 & 80 & 95 & 80 \\
& 5 & 50 & 80 & 100 \\
& Average & 65.0 & 87.5 & 90.0 \\
BO & 6 & 50 & 35 & 35 \\
& 7 & 80 & 90 & 65 \\
& 8 & 60 & 65 & 60 \\
& Average & 63.3 & 63.3 & 53.3 \\
\hline
\end{tabular}

chyos (L.) Link and Prickly caterpillar Scorpiurus muricatus L., although species forming ruderal and nitrophilous assemblages were by far the most abundant; these included Purple viper's bugloss Echium plantagineum L., Cress rocket Carrichtera annua (L.) DC., Sow thistle Sonchus oleraceus L., and the allochthonous Sorrel Oxalis pes-caprae L. The largest cover increase of species typical to more mature successional stages (i.e., grasses and woody spe- 
cies) occurred in the areas where biomats were used.

The regular visual monitoring activities (e.g., no stone rolled from the slope to the beach and no clay accumulation has been recorded after interventions) suggest that erosion is decreasing. Reduction of soil erosion processes is also supported by photographs (Fig. 3) clearly showing the aesthetical improvement of one of the most attractive beaches in Italy.

\section{Discussion and conclusions}

We report on a successful case-study of restoration concerning Mediterranean coastal environments that combined bioengineering, biotechnology, and agronomic practices using autochtonous herbs and shrubs. The work, implemented at Lampedusa, is one of the few carried out on Italian islands and appears to be consistent with the guidelines concerning the ecological restoration and biological conservation quoted in the briefing notes released by the Society for Ecological Restoration (SER 2008).

As erosion and plant diversity conservation problems are quite common along Mediterranean coasts, the strategies and approaches described in this report may be used for similar interventions in the neighbouring Mediterranean countries.

Both planting of native species and the construction of fences slowed surface water flow and soil erosion, thus enhancing plant survival and establishment. Moreover, it is not surprising that recent data on sea turtle nesting show a sensitive increase of oviposition frequency (Prazzi et al. 2010). The promising results obtained so far encourage the protection of areas that are vital for preserving biodiversity and the implementation of restoration efforts in similar environments along the Mediterranean coast.

Up to now, most of bioengineering installations carried out in Italy involved the use of heavy equipment and the movement of large amount of soil. The current study shows vice versa that restoration can be cost-effective also with an input of human work alone (Aronson et al. 2006) by transferring to coastal habitats the same bioengineering techniques which have been proved since decades to be effective elsewhere, mostly on mountain environments (Schiechtl 1991).

The restoration experience carried out at SDC suggests that the use of local germplasm for restoration purposes may also succeed to stopping genetic erosion processes going on at local scales and menacing species persistence in front of biotic or abiotic environmental changes (Grassi et al. 2005). Biodiversity loss pattern at Lampedusa shows many common features with other insular territories (Kingston \& Waldren 2005, Deidun 2010). Thanks to this restoration project, plant diversity at Lampedusa Is- land has been preserved, and the individuals of rare species established on the restored site can now serve as source material for the restoration at other sites. Results are encouraging especially for the locally rare species Arbutus unedo, Myrtus communis, Anagyris foetida. As for other recent restoration interventions (Krauss \& He 2006), they also underline the crucial importance of developing nursery farming to enhance the production chain of plants obtained by autochthonous germplasm, thus avoiding genetic pollution. Furthermore, the project clearly shows that combining restoration ecology with in situ instead of ex situ conservation may overcome many problems underlined by Piotto et al. (2010).

The current study also increased our understanding of restoration practices to be applied within the Mediterranean realm (Valladares \& Gianoli 2007) and confirms that a better knowledge of plant auto-ecology is essential for successful interventions (Bochet et al. 2010).

Some plant species also benefited of microbial inoculation that improved their growth and establishment; microsymbiont inoculation confirmed to be a promising strategy for the recovery of Mediterranean soils, being not more expensive than soil amending or the replacement of dead plants. Management of indigenous plant-microbe symbioses aids restoration of desertified ecosystems and disturbed/anthropogenic soils (Requena et al. 2001, Cardinale et al. 2010). According to field surveys, re-vegetation was successful in that native plant cover has been substantially increased and because soil erosion is now controlled. We expect that plant community should gradually evolve to include subshrubs typical to local garrigue communities.

The present report suggests also once again that the enhancement of plant succession does not require the use of "pioneer" species such as Aleppo pine. In fact, at Lampedusa, as in many other Mediterranean areas (Maestre et al. 2003, Bellot et al. 2004, Ginsberg 2006), dense artificial plantations with Pinus halepensis Mill. have caused substantial losses of species and habitat diversity (Pasta et al. 2012). On the other hand, Aleppo pine was once present on the island as a native plant. Future plantations using local remnant germplasm should therefore be encouraged to get natural-like open woodlands and joining the advantage of tree coverage without a severe damage to local natural heritage.

The activity carried out at Lampedusa is the result of a fruitful interaction between academic research and local environmental management. This is considered a basic element supporting the restoration process of Mediterranean areas (Khater et al. 2011). Public has been informed about the need and the aims of the restoration effort and its suc- cess has a positive effect on people, in total agreement with the so-called "socially robust restoration strategies" (Gross 2006). The project also allowed to control and minimize the human impact caused by people visiting the beach. By means of boards and other educational material, the public is now informed about the importance of protecting sea turtle breeding sites, plants and habitats. Bathing is regulated to minimize environmental disturbance, while still allowing visitors to enjoy one of the most beautiful beaches of Italy.

\section{Acknowledgements}

The research, partially supported by EUProject Life03 NAT/IT7000163 "Reduction of human impact on Caretta caretta and Tursiops truncatus and their conservation in Sicily", was promoted by the Province of Agrigento in collaboration with AGCI Pesca, CTS, Legambiente Sicilia, Telespazio, and the University of Turin. The research was partially supported by the project "Analisi dei sistemi seminaturali e degli agro-ecosistemi nei sistemi insulari mediterranei: Isola di Lampedusa e pantani di Vendicari" funded by the Regione Siciliana, Assessorato Risorse Agricole e Alimentari - Dipartimento Interventi Infrastrutturali, Area Studi e Programmazione; on this purpose we especially thank A. Drago, F. Guaitoli and G. Matranga. We are very grateful to S.A.VI.F. Vivai Piante s.r.l. (Agricultural Society and Forestry Nursery) of Caltanissetta which cared plants' propagation and to B. Jaffee for revising the English version of the manuscript. We also thank two anonymous reviewers for their valuable comments to the manuscript and their constructive suggestions.

\section{References}

Anonymous (2002). European platform for biodiversity research strategy. Scientific responses to threats in Mediterranean ecosystems: conservation, mitigation and restoration. Communications to the electronic conference $15^{\text {th }}-28^{\text {th }}$ April 2002. [online] URL: http://www.biostrat.org/ Mediterranean ecosystems - Spain.pdf

Aronson J, Clewell AF, Blignaut JN, Milton SJ (2006). Ecological restoration: a new frontier for nature conservation and economics. Journal for Nature Conservation 14: 135-139. - doi: 10.1016/j.jnc.2006.05.005

Bartolo G, Brullo S, Minissale P, Spampinato G (1990). Flora e vegetazione dell'isola di Lampedusa. Bollettino dell'Accademia Gioenia di Scienze Naturali 21 (334): 119-255.

Bellot J, Maestre FT, Chirino E, Hernández N, de Urbina JO (2004). Afforestation with Pinus halepensis reduces native shrub performance in a Mediterranean semiarid area. Acta Oecologica 25(1-2): 7-15. - doi: 10.1016/j.actao.2003.10. 001

Bochet E, García-Fayos P, Tormoy J (2010). How 
can we control erosion of roadslopes in semiarid mediterranean areas? Soil improvement and native plant establishment. Land Degradation \& Development 21 (2): 110-121. - doi: 10.1002/ldr. 911

Bombace M, De Domenico R, Lo Valvo F, Nicolini G (2001). Interventi finalizzati alla salvaguardia del sito di ovideposizione della tartaruga marina Caretta caretta L. a Lampedusa. Il Naturalista siciliano 25: 111-119.

Bothe H, Turnau K, Regvar M (2010). The potential role of arbuscular mycorrhizal fungi in protecting endangered plants and habitats. Mycorrhiza 20(7): 445-457. - doi: 10.1007/s00572010-0332-4

Braun-Blanquet J (1932). Plant sociology. Mc Graw-Hill, New York, USA and London, UK. Brullo C, Brullo S, Giusso del Galdo G, Guarino R, Minissale P, Scuderi L, Siracusa G, Sciandrello S, Spampinato G (2010). The Lygeo-Stipetea class in Sicily. Annali di Botanica pp. $57-$ 84.

Cardinale M, Brusetti L, Lanza A, Orlando S, Daffonchio D, Puglia AM, Quatrini P (2010). Rehabilitation of Mediterranean anthropogenic soils using symbiotic wild legume shrubs: plant establishment and impact on the soil bacterial community structure. Applied Soil Ecology 46: 1-8. - doi: 10.1016/j.apsoil.2010.05.007

Cardinale M, Lanza A, Bonnì ML, Marsala S, Puglia AM, Quatrini P (2008). Diversity of rhizobia nodulating wild shrubs of Sicily and some neighbouring Islands. Archives of Microbiology 190: 461-470. - doi: 10.1007/s00203008-0394-2

Conti F, Abbate G, Alessandrini A, Blasi C (2005). An annotated checklist of the italian vascular flora. Ministero dell'ambiente e della tutela del territorio, Direzione per la protezione della natura, Dip. Biologia Vegetale "La Sapienza", Università degli Studi di Roma. Palombi Ed., Rome, Italy.

Conti F, Manzi A, Pedrotti F (1997). Liste Rosse Regionali delle Piante d'Italia. WWF-Società Botanica Italiana, Camerino, pp. 139.

De Dato GD, Loperfido L, De Angelis P, Valentini R (2009). Ricolonizzazione assistita in aree semi-aride mediterranee: un caso di studio. In: Atti del "Terzo Congresso Nazionale di Selvicoltura". Taormina (ME), 16-19 ottobre 2008. Accademia Italiana di Scienze Forestali pp. 13421348. [online] URL: http://www.aisf.it/Att CNS/pdf/volume\%203/3.31\%20de\%20Dato.pdf Deidun A (2010). Challenges to the conservation of biodiversity on small islands: the case study of the Maltese islands. Journal of Arts and Sciences 3 (8): 175-187.

Eichberger C (2001). Die Baumartige Wolfsmilch Euphorbia dendroides L. Biologie, Ökologie, Pflanzensoziologie un soziokulturelle Stellung einer mediterraner Art. Dissertationes Botanicae 344: 1-351.

Ennajeh M, Cochard H, Khemira H (2010). Re-introduction success of an autochthonous plant species, Periploca angustifolia, in the Natural Reserve of Oued Dekouk, Tunisia. Spanish
Journal of Agricultural Research 8(4): 1005 1011. [online] URL: http://herve.cochard.free.fr/ pdf/Ennajeh_et_al_2010_SJAR.pdf

Ferro V (2006). La sistemazione dei bacini idrografici (2 edn). McGraw-Hill, pp. 872.

Ginsberg P (2006). Restoring biodiversity to pine afforestations in Israel. Journal for Nature Conservation 14 (3-4): 207-216. - doi: 10.1016/ j.jnc.2006.04.003

Grassi F, Cazzaniga E, Minuto L, Peccenini S, Barberis G, Basso B (2005). Evaluation of biodiversity and conservation strategies in Pancratium maritimum $\mathrm{L}$. for the northern Tyrrhenian Sea. Biodiversity and Conservation 14: 21592169. - doi: 10.1007/s10531-004-4666-0

Gross M (2006). Beyond expertise: ecological science and the making of socially robust restoration strategies. Journal for Nature Conservation 14 (3-4): 172-179. - doi: 10.1016/j.jnc.2006.05. 004

Khater C, Raevel V, Sallantin J, Thompson JD, Hamze M, Martin A (2011). Restoring ecosystems around the Mediterranean basin: beyond the frontiers of ecological science. Restoration Ecology. - doi: 10.1111/j.1526-100X.2011. 00827.x

Kingston N, Waldren S (2005). A conservation appraisal of the rare and endemic vascular plants of Pitcairn Island. Biodiversity and Conservation 14: 781-800. - doi: 10.1007/s10531-004-0658-3

Krauss SL, He TH (2006). Rapid genetic identification of local provenance seed collection zones for ecological restoration and biodiversity conservation. Journal for Nature Conservation 14 (3-4): 190-199. - doi: 10.1016/j.jnc.2006.05.002

La Mantia T (2001). L'estinzione della Damigella di Numidia Anthropoides virgo (L.) a Lampedusa: un esempio di rarefazione della fauna mediterranea. Il Naturalista siciliano 25(1-2): 255-259. [online] URL: http://www.unipa.it/arbor/pubblicazioni_per_docente/lamantiat.htm

La Mantia T, Carimi F, Di Lorenzo R, Pasta S (2011). The agricultural heritage of Lampedusa (Pelagie Archipelago, S Italy) and its key role for cultivar and wildlife conservation. Italian Journal of Agronomy 6 (12): 106-110. [online] URL: http://agronomy.it/index.php/agro/article/view/ij a.2011.e17/315

La Mantia T, Livreri Console S, Pasta S (2005). Un contributo alla conservazione della biodiversità in Sicilia. Alberi e Territorio II: 42-47. [online] URL: http://www.unipa.it/arbor/pubblicazioni per docente/lamantiat.htm

La Mantia T, Pasta S, Rühl J (2009). Parte I - Fase conoscitiva - Flora e vegetazione, habitat comunitari, uso del suolo al Piano di Gestione "Isole Pelagie", POR 1999.IT.16.1.PO.011/ 1.11/11.2.9/0304, Legambiente-Comitato Regionale Siciliano e Dipartimento di Colture Arboree dell'Università degli Studi di Palermo. [online] URL: http://www.artasicilia.eu/web/natura2000/index.html

La Mela Veca DS, Pasta S, Sessa K, La Mantia T (2003). Censimento e tutela delle formazioni vegetali naturali fuori foresta: il caso di Lampedusa (Arcipelago delle Pelagie). Italia Forestale e
Montana 3: 191-201. [online] URL: http://www. unipa.it/arbor/biblioteca/lavori pdf/tlamantia/Ce nsimento $\% 20 \mathrm{e} \% 20$ tutela $\% 20$ delle $\% 20$ formazioni\%20veegtali\%5B1\%5D.pdf

Le Houérou HN (2004). Diversité botanique de la Marmarique (Libye et Egypte): catalogue des plantes vasculaires inventoriées avec leur biologie, répartition, fréquence, usage économique, habitat et caractéristiques écologiques principales, suivi d'une bibliographie étendue. Candollea 59: 259-308. [online] URL: http://www.ville-ge.ch/cjb/publications/cando592/C592_259-308.pdf

Maestre FT, Cortina J, Bautista S, Bellot J (2003). Does Pinus halepensis facilitate the establishment of shrubs in Mediterranean semi-arid afforestations? Forest Ecology and Management 176 (1-3): 147-160. - doi: 10.1016/S0378-1127(02) 00269-4

Maestre FT, Cortina J, Vallejo R (2006). Are ecosystem composition, structure, and functional status related to restoration success? A test from semiarid Mediterranean steppes. Restoration Ecology 14(2): 258-266. - doi: 10.1111/j.1526100X.2006.00128.x

Menegazzi G, Messana G (2010). Stop all'erosione. ACER 1: 57-61.

Nicolini G (2001). La riserva naturale "Isola di Lampedusa". Il Naturalista siciliano 25 (3-4): 917.

Onori L (2009). Il ripristino degli ecosistemi marino-costieri e la difesa delle coste sabbiose nelle Aree protette. ISPRA Rapporti N 100/2009, pp. 674. [online] URL: http://www.isprambiente.gov.it/files/pubblicazioni/rapporti/ra pporto-100-2009-cap-1-11.pdf-http://www.isprambiente.gov.it/files/pubblicazioni/rapporti/ra pporto-100-2009-cap-12-14.pdf

Padilla FM, Ortega R, Sánchez J, Pugnaire FI (2009). Rethinking species selection for restoration of arid shrublands. Basic and Applied Ecology 10 (7): 640-647. - doi: 10.1016/j.baae.2009. 03.003

Pasta S (2001). Contributi alla conoscenza botanica delle isole minori circumsiciliane. I. Sintesi aggiornata delle conoscenze botaniche sull'Isola di Lampedusa finalizzata alla conservazione delle sue emergenze floristico-vegetazionali. Il Naturalista Siciliano 25: 19-70.

Pasta S, La Mantia T (2003). Note sul paesaggio vegetale delle isole minori circumsiciliane. II. La vegetazione pre-forestale e forestale nelle isole del Canale di Sicilia: dalla ricostruzione storica alla gestione futura. Annali dell'Accademia Italiana di Scienze Forestali LI: 77-124. [online] URL: http://www.unipa.it/arbor/biblioteca/lavori_pdf/tlamantia/Note $\% 20$ sul $\% 20$ paesaggio $\% 20$ vegetale $\% 20$ delle $\% 20$ isole $\% 20$ minori $\% 5 B 1 \% 5 \mathrm{D}$.pdf

Pasta S, La Mantia T, Rühl J (2012). The impact of Pinus halepensis Mill. afforestation on Mediterranean spontaneous vegetation: do soil treatment and canopy cover matter? Journal of Forest Research 23(4): 517-528. - _ doi 10.1007/s11676-012-0292-y

Pignatti S (1982). Flora d'Italia. Edagricole, Bo- 
logna.

Piotto B, Giacanelli V, Ercole S (2010). La conservazione ex situ della biodiversità delle specie vegetali spontanee e coltivate in Italia. Stato dell'arte, criticità e azioni da compiere. Manuali e linee guida. ISPRA $54 / 2010$, pp. 205. [online] URL: http://www.cbd.int/iyb/doc/celebrations/ iyb-Italy-ISPRA-article-it.pdf

Piotto B, Di Noi A (2001). Propagazione per seme di alberi e arbusti mediterranei. Manuale ANPA, pp. 212.

Prazzi E, Nicolini G, Piovano S, Giacoma C (2010). Protezione di Caretta caretta (Reptilia Chelonia) nella Riserva Naturale di Lampedusa. Il Naturalista siciliano 34 (3-4): 265-294. [online] URL: http://www.sssn.it/PDF/PDF\%20NS \%2034/265-294.pdf

Requena N, Pérez-Solis E, Azcón-Aguilar C, Jeffries P, Barea JM (2001). Management of indigenous plant-microbe symbioses aids restoration of desertified ecosystems. Applied and Environ- mental Microbiology 67 (2): 495-498. - doi: 10.1128/AEM.67.2.495-498.2001

Rivas-Martínez S (2008). Global bioclimatics (Clasificación biclimática de la Tierra). [online] URL: http://www.globalbioclimatics.org

SER (2008). Opportunities for integrating ecological restoration \& biological conservation within the ecosystem approach (briefing note). [online] URL: http://www.ser.org/pdf/SER_Briefing_Note_May_2008.pdf

Schiechtl HM (1991). Bioingegneria forestale. Edizioni Castaldi, Feltre, Italy.

Tinelli A, Tinelli P, Maffei L (2010). I sistemi dunali. In: "Restauro della foresta mediterranea" (Mercurio R ed). CLUEB, Bologna, Italy, pp. 291-306.

Turrini A, Giovannetti M (2012). Arbuscular mycorrhizal fungi in national parks, nature reserves and protected areas worldwide: a strategic perspective for their in situ conservation. Mycorrhiza 22(2):81-97. - doi: 10.1007/s00572-011-
0419-6

Valladares F, Gianoli E (2007). How much ecology do we need to know to restore Mediterranean ecosystems? Restoration Ecology 15 (3): 363-368. - doi: 10.1111/j.1526-100X.2007. 00230.x

Wickens GE (1998). Ecophysiology of economic plants in arid and semi-arid lands. Springer Berlin Heidelberg New York, pp. 349.

Vallejo VR, Aronson J, Pausas JG, Cortina J (2006). Restoration of mediterranean woodlands. In: "Restoration ecology" (Van Andel J, Aronson J eds). The New Frontier, Blackwell Publications, Oxford, UK, pp. 193-207.

Zahran HH (2001). Rhizobia from wild legumes: diversity, taxonomy, ecology, nitrogen fixation and biotechnology. Journal of Biotechnology 91 (2-3): 143-53. - doi: 10.1016/S0168-1656(01) $00342-\mathrm{X}$ 